\title{
Selected papers of young analytical chemists
}

\author{
Karel Nesměrák ${ }^{1}$ (D) $\cdot$ Tomáš Navrátil ${ }^{2}$
}

Received: 23 July 2018 / Accepted: 24 July 2018/Published online: 10 August 2018

(C) Springer-Verlag GmbH Austria, part of Springer Nature 2018

Dear readers,

This special issue of Monatshefte für Chemie-Chemical Monthly brings a nice selection of papers written by young and beginning analytical chemists. We are pretty aware, that the blossoming of such crucial science as it is analytical chemistry lays in the continuous development of new talents.

The art of scientific writing is one of the most crucial parts of Ph.D. education. Therefore, with generous consent of the Editor-in-Chief of the journal, Prof. Dr. Peter Gärtner, we present here the selection of the most interesting papers written by Ph.D. students. Our aim is to support their creativity and research activities in the field of analytical chemistry. The topics cover almost all the aspects of modern analytical chemistry encompassing the improvement of calibration methods, development of new analytical methods and techniques, and the application of analytical chemistry to solve nutritional, medicinal, and historical problems. All these contributions were written by authors on personal invitation, with some, but not all of them, being participants at 13th international students' conference "Modern Analytical Chemistry", held at the Department of Analytical Chemistry, Faculty of Science, Charles University, Czech Republic, on September 21 and 22, 2017.

We hope that affable readers will find presented contributions interesting and they will be assured that a new generation of analytical chemists will secure bright and exciting future of analytical chemistry. In that way, analytical chemistry will remain rewarding, exciting, steadily developing science with vivid perspectives and new, unsuspected ways of its innovation and application.

As Editors of this special issue we would like to express our deep gratitude to the Editor-in-Chief, Prof. Dr. Peter Gärtner, and the Managing Editor, Dr. Christian Hametner, for their great support in the preparation of the issue. We also would thank all referees for valuable comments that helped to improve the quality of the manuscripts, and to the staff of the Publisher, Springer Vienna, for all their contributions to the special issue release.

Sincerely, Karel Nesměrák and Tomáš Navrátil

Karel Nesměrák

nesmerak@natur.cuni.cz

1 Department of Analytical Chemistry, Faculty of Science, Charles University, Prague, Czech Republic

2 J. Heyrovský Institute of Physical Chemistry of the CAS, v.v.i., Prague, Czech Republic 